moted chief of the Bureau of Chemistry. Then it was that food reform became his master passion.

Wiley resigned in 1912, after great provocation. The Food and Drugs Law had been enacted after half a century of effort and discussion. The measure came into operation in January 1907. Almost at once, he has told us, he discovered that his point of view was fundamentally different from that of his superiors. During six years the feeling grew that the differences were irreconcilable and he became conscious of an environment which was essentially inhospitable. The fundamental principles of the Bill, as they appeared to him, one by one, were paralysed and discredited. It is easy to imagine what happened: the thorn he must have been in the side of the provision trade and the attempts that will have been made to unseat him. Convinced that he could work more fruitfully by rallying public opinion to the support of the cause he had so much at heart than by exercising the limited activity left to him in his official position, he resigned. On retiring into private life, he interested himself in his farm and became a diffuse, popular writer of food propaganda.

We have, I think, to quarrel severely with Wiley's extreme attitude towards preservatives in food. His view was that there should be no addition of any kind made to food. As the primrose to Peter Bell, every food spade, to the public, was to be a spade absolute, nothing more. His most celebrated work is the inquiry he undertook, with a set of young men as subjects, to ascertain the effect of preservatives, especially boric acid: the results were recorded in a very lengthy report of about 2000 pages. Grave exception has been taken to this work. He was probably not qualified, either as chemist or biologist, to undertake such an inquiry: he was far too much a victim of preconceived opinion and not sufficiently trained either as observer or as logician. He would have excluded every preservative. Owing, however, to Ira Remsen's intervention, whose higher scientific standing prevailed, benzoic acid was allowed. Wiley, I believe, managed later to persuade the President to subvert this decision.

As is well known, within recent years, our Ministry of Health, which is a hive of idealisms, has followed the American suit. No scientific proof has yet been given that, used as an antiseptic, boric acid does harm when added in the small amounts needed to preserve even so perishable an article as cream. The officials of the Ministry are no more competent than Wiley was to settle such an issue. The decision was taken by a Departmental Committee on idealistic grounds. As a result, the cream industry is severely dislocated, if not destroyed. The public have full right to complain, the more as sulphur dioxide is still allowed in some beverages : its evil effect is well known to many who go to public dinners. I hold no brief; $\mathrm{my}$ mind is open. I know what the danger is in lead works, when there is real exposure. I also know the great boric acid works in Tuscany ; these reek of the acid in every direction-yet the workpeople are all healthy. If only in justice to Wiley's memory, we ought, without delay, to study the problem afresh scientifically, with complete thoroughness and detachment, so that we may either justify or cancel his finding. It is farcical for us to hold the cake of science and not eat it. We can't afford such extravagance to-day.

Henry E. Armstrong.

\section{Mrs. Albert Howard}

A sEvere blow has been dealt to the progress of science in India through the death at the age of fiftythree years of Mrs. Albert Howard, which took place at Geneva on Aug. 18 last. Miss G. L. C. Matthaei entered Newnham College, Cambridge, in 1895 and secured the double distinction of a first class in both parts of the Natural Science Tripos. Thereafter she continued to reside at Cambridge, being elected a fellow, and later an associate, of her College. She was fortunate at that time in coming under the powerful influences of Miss Ida Freund and Dr. F. F. Blackman. Her work in association with the latter developed in her a capacity for patient pursuit of the elusive in research which was so marked a characteristic of her work to the last. That early work is to be found in the Philosophical Transactions of the Royal Society, and has found a permanent niche in the literature on vegetable assimilation.

From 1905, when she married Mr. Albert Howard, the scene of her activities shifted to India. With that marriage commenced a comradeship which, if not unique in the annals of science, is at least unique in that it received official recognition from the Government of India, for, in 1910, she was appointed personal assistant to her husband and, in 1913, Second Imperial Economic Botanist. She was also awarded, by H.M. the King, the Kaisar-i-Hind medal of the First Class.

It is not possible, even for one who has had the privilege of sharing in part of the labours of the Howards in India, to apportion merit between the two comrades. Their work stands, and is best left, as a joint record of their devotion to each other and to India. But Mrs. Howard's association with Pusa introduced a definite economic trend, absent from her earlier work but becoming more and more marked with time. In 1905 the Agricultural Department in India was but recently reorganised and the impetus given by the rediscovery of Mendel's work was still fresh. The earlier papers are tinged by these facts and many plant breeding problems in this new field were brought to solution by these new methods. But even at this period the economic aspect was not neglected, as the 'Pusa wheats', already entering into general cultivation, and now covering more than three million acres, witness. This earlier work culminated in the monograph on "Wheat in India ", and thereafter an ever-widening field opened out. The logic of a position in a country where rotations are habitually practised cannot be denied; the whole field of crop production and the methods of applying science thereto becomes the centre of investigation. This urge to a wider field of

No. 3177, VoL. 126] 
investigation is traceable through the large series of publications which have appeared. It is an urge which found its consummation in the foundation of the Institute of Plant Industry at Indore, where the last six years of her life's work have been conducted.

The same widening outlook found an outlet in the first proposals for the founding of an Indian Science Congress. In that movement Mrs. Howard took a deep personal interest and she presided over both the Botanical and Agricultural Sections. It is not possible to estimate the material benefit of her work to India-undoubtedly it has been great; but the greater loss is that which arises from the balanced judgment, on both scientific and practical problems, which she was ever ready to place at the disposal of all who sought it.

\section{Prof. Jean Brunhés.}

JEAN BRUNHés, the French geographer, who died at Boulogne-sur-Seine on Aug. 25 at the age of sixty-one years, was one of the leading exponents of human geography of his time. By his teaching and published works he did much to put the subject on a sound scientific basis, and to lift it from the narrow lines of geographical determinism into which it tended to fall some years ago.

Brunhés was born at Toulouse and studied law at the university there before turning to science at the Ecole Normale. His first work was on the geographical conditions of irrigation in Spain and Northern Africa. This was published in 1902 and. showed a grasp of geographical correlations and a width of outlook. Much of his later work was done during the sixteen years when he held the chair of geography in the University of Fribourg, to which he was the first appointment.

In 1910 Brunhés published his "Géographie Humaine", which immediately became a standard work and has remained so to this day. It was afterwards expanded into a much larger work, and it also appeared, with some changes, in an English edition. Brunhés was also responsible for the geographical chapters in Gabriel Hanotaux's great history of France. These constitute a whole volume entitled. "Géographie humaine de la France". A third important work was his "Géographie de l'histoire". According to the Times, he was engaged at the time of his death on a history of races. Brunhés was elected a member of the Institut de France in 1927.

WE regret to announce the following deaths:

Mr. Walter Deane, a past president of the New England Botanical Club, who was known for his work on the flora of north-eastern North America, on July 30, aged eighty-two years.

Prof. Cornelius Doelter, emeritus professor of mineralogy in the University of Vienna, and author of works on chemical mineralogy and related topics, on Aug. 8, aged seventy-nine years.

Mr. Henry W. Henshaw, formerly chief of the Biological Survey of the U.S. Department of Agriculture, and author of "Birds of the Hawaiian Islands," on Aug. 1, aged eighty years.

Dr. Wyatt W. Randall, formerly chief of the Maryland Department of Health, and president in 1926 of the Association of Official Agricultural Chemists, on July 22, aged sixty-three years.

Mr. J. W. Wilson, from 1892 until 1908 president of the Society of Engineers and co-founder with his father of the Crystal Palace School of Engineering in 1872 , on Sept. 3, aged seventy-eight years.

\section{News and Views.}

Is our last issue (Nature, Sept. 13, p. 391) we referred to the measures which are being taken or are under consideration by the Commonwealth Government of Australia to ameliorate conditions among the aborigines. Of the suggestions which have been made, the most important is undoubtedly that which recommends that the aborigines as a whole should come under the control of the Commonwealth Government. It involves many difficulties and would entail numerous adjustments as between the Commonwealth and State authorities ; the obstacles, however, should not be insuperable, and the advantages which would accrue are too great to be lost without determined effort. Not the least of these would be that continuity and uniformity in policy could be secured by one authority dealing with the aboriginal question as a whole; and further, a wider and more effective public opinion would be brought into play when any question affecting policy or any specific measure was under consideration. All competent observers are agreed that in present conditions the extinction of the aborigines is a matter of only a comparatively brief period. With the lamentable example of the extinct Tasmanians to point the moral, no measure, however difficult of achievement, should be left untried to avert a similar fate from the Australian tribes, in some cases, unfortunately, already reduced to the merest fragment.

THE question of the aborigines is more than a domestic matter which concerns Australia alone. Apart from humanitarian considerations, the question touches a wide circle of interests in the world of science. At the recent Bristol meeting of the British Association a resolution submitted to the Council pointed out that the Australian aborigines are now among the most valuable peoples available for scientific study, and offer opportunities of unequalled importance for research and future investigation in the early history of mankind. The resolution, while recognising the value of the measures now proposed by the Commonwealth Government, went on to ask the Council to urge upon that Government the need for anthropological training for officials entrusted with the administration of the affairs of the aborigines and the adoption of every means to prevent their extinction and the further disintegration of native society. Notwithstanding the economic and financial 